\title{
DATA ABOUT THE AUTHOR
}

Tetiana Rybakova, Ph.D. in Economics, Associate Professor in the Department of Economics Hryhorii Skovoroda University in Pereiaslav

30, Sukhomlynsky Str., Pereiaslav, Ukraine, 08401

e-mail: taryb@ukr.net

Подано до редакції 01.12.2021

Прийнято до друку 18.12.2021

\section{ПОДАТОК НА ДОДАНУ ВАРТІСТЬ ТА ЙОГО МІСЦЕ В СИСТЕМІ НЕПРЯМИХ ПОДАТКІВ}

Предметом дослідження $є$ податок на додану вартість.

Слюсар C. T.

Метою статmі є механізм функціонування ПДВ в Україні та розробка пропозицій щодо його адміністрування з урахуванням інтеграційних процесів в Україні.

Методологічною основою дослідження $\epsilon$ загальнонаукові та спеціальні методи наукового пізнання, а саме: системний підхід, структурування, аналіз і синтез.

Результати роботи. На сьогодні в Україні однією з основних економічних проблем є вдосконалення податкової системи загалом і системи оподаткування зокрема. Удосконалення оподаткування податком на додану вартість як складової системи оподаткування є важливим практичним завданням та однією $з$ актуальних загальноекономічних проблем, що потребує вирішення. Питання удосконалення відшкодування ПДВ, підвищення рівня його ефективності, погашення заборгованості з відшкодування і запобігання ї виникнення у майбутньому - пріоритетні в розробленнях науковців та в практичній діяльності органів ДПС. Податок на додану вартість $є$ одним із найбільш суперечливих податків, тому через наявність істотних проблем при його справлянні, може перетворитися з бюджетотвірного в бюджетовитратний [1]. Актуальність питання щодо сплати ПДВ потребує подальшого глибокого аналізу, враховуючи економічну ситуацію країни, сучасний стан і специфріку функціонування податкової системи.

Галузь застосування результатів: Міністерство фрінансів України, Верховна Рада України, органи місцевого самоврядування, територіальні громади.

Висновки. Податок на додану вартість $є$ одним з найбільших джерел доходів державного бюджету країни. Основною проблемою адміністрування ПДВ стало подальше проведення експерименті із змінами в податковому законодавстві. Україна на сучасному етапі розвитку потребує вжиття додаткових законодавчих та адміністративних заходів, спрямованих на удосконалення справляння, податку.

Ключові слова: податок на додану вартість, механізм, фріскальна ефективність, оподаткування, гармонізація податкової політики.

\section{НАЛОГ НА ДОБАВЛЕННУЮ СТОИМОСТЬ И ЕГО МЕСТО В СИСТЕМЕ КОСВЕННЫХ НАЛОГОВ}

Предметом исследования является налог на добавленную стоимость.

Слюсар C. T.

Целью статьи является механизм фрункционирования НДС в Украине и разработка предложений по его администрированию с учетом интеграционных процессов в Украине.

Методологической основой исследования являются общенаучные и специальные методы научного познания, а именно: системный подход, структурирование, анализ и синтез.

Результаты работы. На сегодняшний день в Украине одной из основных экономических проблем является совершенствование налоговой системы в целом и системы налогообложения в частности. Совершенствование налогообложения налогом на добавленную стоимость как составляющей системы налогообложения является важной практической задачей и одной из актуальных общеэкономических проблем, требующих решения. Вопросы усовершенствования возмещения НДС, повышения уровня его эффрективности, погашения задолженности по возмещению и предотвращения ее возникновения в будущем - приоритетны в разработках ученых и практической деятельности органов ГНС. Налог на добавленную стоимость является одним из наиболее противоречивых налогов, поэтому из-за наличия существенных проблем при его взимании может превратиться из бюджетообразующего в бюджетозатратный [1]. Актуальность вопроса об уплате НДС требует дальнейшего глубокого анализа, учитывая экономическую ситуацию страны, современное состояние и специфику функционирования налоговой системы.

Область применения результатов: Министерство финансов Украины, Верховная Рада Украины, органы местного самоуправления, территориальные общины.

Выводы. Налог на добавленную стоимость является одним из самых больших источников доходов государственного бюджета страны. Основной проблемой администрирования НДС явилось дальнейшее проведение эксперимента с изменениями в налоговом законодательстве. Украина на 
современном этапе развития требует принятия дополнительных законодательных административных мер, направленных на усовершенствование взимания, налога.

Ключевые слова: налог на добавленную цена, механизм, фискальная эфрективность, налогообложение, гармонизация налоговой политики.

\section{VALUE-ADDED TAX AND ITS PLACE IN THE INDIRECT TAX SYSTEM}

Sliusar Svitlana

The subject of research is value added tax.

The purpose of the article. The purpose of the study is the mechanism of VAT functioning in Ukraine and development of proposals for its administration taking into account integration processes in Ukraine.

The methodological basis of the study is general scientific and special methods of scientific knowledge: systematic approach, structuring, analysis and synthesis.

Results of work. Today, one of the main economic problems in Ukraine is the improvement of the tax system in general and the tax system in particular. Improving taxation with value-added tax as a component of the taxation system is an important practical task and one of the pressing general economic problems that needs to be addressed. Issues of improving VAT reimbursement, increasing its level of efficiency, repayment of compensation arrears and prevention of its occurrence in the future are priority issues in the development of scientists and in the practical activities of the State Tax Service of Ukraine. Value-added tax is one of the most controversial taxes, so because of significant problems in its collection, it can turn from budget-forming to budget-forming. The relevance of the issue of VAT payment requires further in-depth analysis, taking into account the economic situation of the country, the current state and specifics of the tax system.

Field of application of results: Ministry of Finance of Ukraine, the Verkhovna Rada of Ukraine, local selfgovernment bodies, territorial communities.

Conclusions. The value added tax is one of the largest sources of revenue of the state budget of the country. The main problem of VAT administration was the further implementation of the experiment with changes in tax legislation. Ukraine at the present stage of development requires the adoption of additional legislative and administrative measures aimed at improving the collection of the tax.

Keywords: value added tax, mechanism, fiscal efficiency, taxation, harmonization of tax policy.

JEL Classification: R51, H72, O23

The value added tax is the largest source of revenue to the state budget of Ukraine. And in reforming the tax system, when the state tries to approach European standards, VAT administration is one of the main issues. Thus, the article considers the place of indirect taxes in the tax system, namely value added tax (VAT). The stages and features of indirect taxes are defined, the fiscal efficiency of VAT is analysed taking into account the experience of EU member countries.

Value added tax (VAT) is an indirect tax, is part of the newly created value that is generated at each stage of production or circulation, its amount is included in the sales price for goods (works, services) and is paid by the end-user.

Literally, VAT is a value-added tax created at this particular stage of the goods movement, resulting in the elimination of the cumulative (cascading) tax effect.

Problematic issues of value added tax collection were considered by many domestic and foreign economists. The theoretical foundations of value added and value added tax were considered by economists such as: N.I. Redina. A. Marshall, P.G. Gega, G.V. Beh, I.A. Zolotko, K.K. Ullubieva, N.A. Baby, Campbell R. McConnell, Gregory N. Mankiv, K.A. Pribenko, S. Aleksashenko, N. Rivak, M. The historical aspect of the emergence and development of the value added tax was investigated by authors such as: K. James, M.A. Brovenko, V. Enbaev, L.P. Sidelnikova, O.I. Oksenyuk, V.G. Lavrov, E.S. Bratushko and E.V. Konenets. Manifestations of deviant behavior of value-added tax payers, as well as their impact on income volumes, were investigated by such economists as: V.P. Vishnevsky, M. Mamaeva, E.B. Atkinson and Yu. Dzhigir. The issues of increasing the fiscal effectiveness of the value added tax and the possibilities for its improvement in the context of European integration were considered by such scientists as: I.V. Baranovskaya, O.Yu. Dubovik, E.A. Moldovan, P.L. Kulik, Ya. V. Samusevich, L.M. Demidenko, Yu.L. Subbotovich and V. A. Shevchuk.

In fact, the value added approaches the newly created value (part of the national income) produced in this economic structure (link). The determination of value added allows you to calculate all the taxes that this business unit has paid when purchasing goods (works, services). Assuming that the value added is the generated profit or the value of the net product, the value added is determined by adding its constituent elements - wages, interest, rents and profits.

In the statistical calculation, the value added indicator can be defined as the difference between the value of the goods sold and the costs of their production and sale, between the total amount of sales and the total amount of purchases from all economic entities.

Figure 1 and table 1 illustrate value addition and VAT.

During each act of purchase and sale, tax is charged at the standard rate, but is actually paid in the amount reduced by the amount of VAT paid at the previous stage (these values are shown in table 1, column 8 ). The end consumer pays the goods at the price increased by the entire amount of VAT payments advanced at the previous stages of production and movement of the goods. 


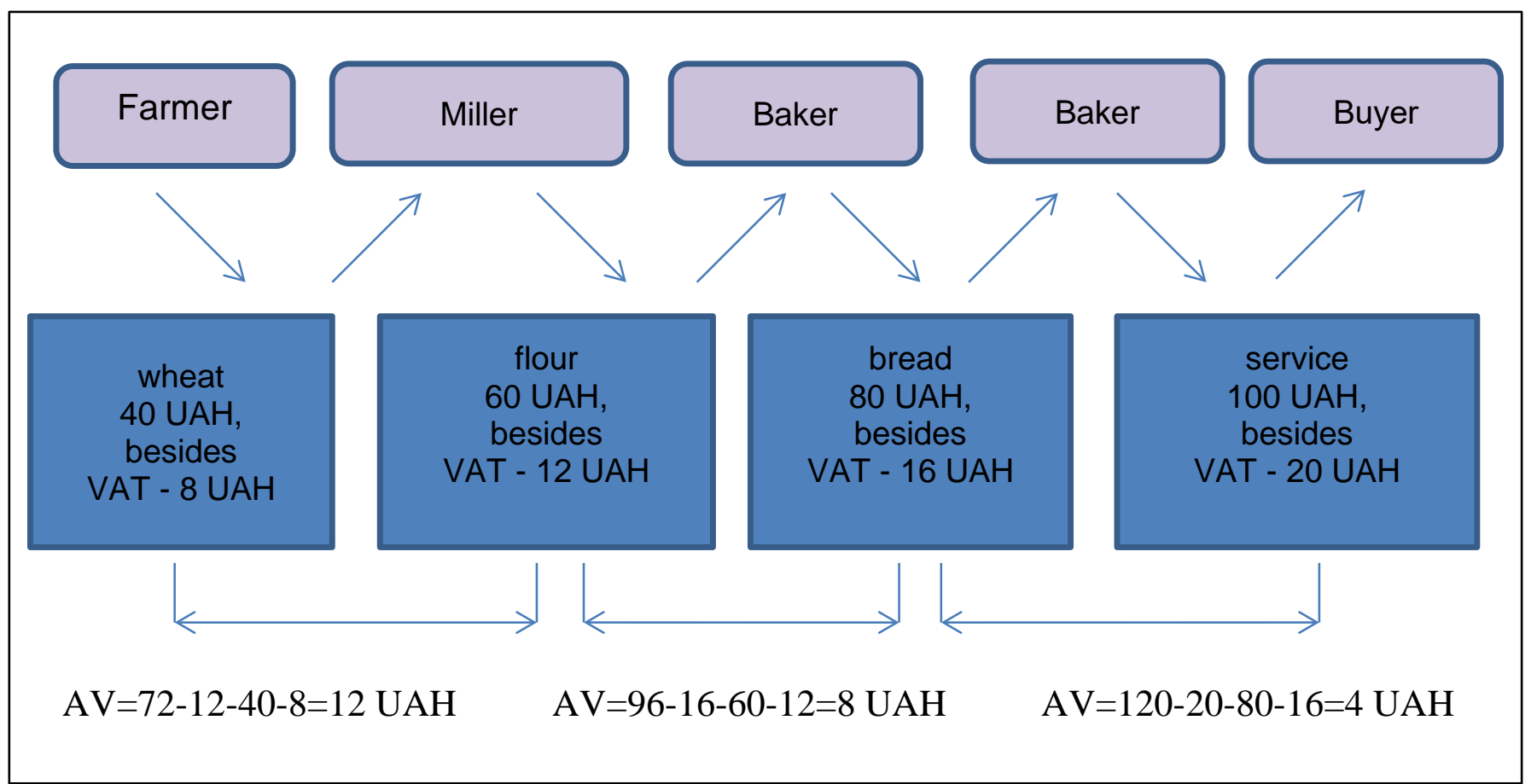

Fig. 1. Creating value added as a taxable object

Source: Developed by the author

Table 1. Creating value added as a taxable object

\begin{tabular}{|c|c|c|c|c|c|c|c|c|}
\hline Enterprise & $\begin{array}{c}\text { Item value } \\
\text { (including VAT) }\end{array}$ & $\begin{array}{c}\text { Includes } \\
\text { cost price }\end{array}$ & $\begin{array}{c}\text { Added } \\
\text { value }\end{array}$ & $\begin{array}{c}\text { Cost of } \\
\text { goods sold }\end{array}$ & $\begin{array}{c}\text { VAT of } \\
20 \%\end{array}$ & $\begin{array}{c}\text { Account to } \\
\text { the buyer }\end{array}$ & $\begin{array}{c}\text { Earlier } \\
\text { paid tax }\end{array}$ & $\begin{array}{c}\text { Paid in the } \\
\text { budget (col.6 - } \\
\text { col.8) }\end{array}$ \\
\hline 1 & 2 & 3 & 4 & 5 & 6 & 7 & 8 & 9 \\
\hline Farmer & - & - & $40^{\star}$ & 40 & 8 & 48 & - & 8 \\
\hline Miller & 48 & 40 & 12 & 60 & 12 & 72 & 8 & 4 \\
\hline Baker & 72 & 60 & 8 & 80 & 16 & 96 & 12 & 4 \\
\hline Baker & 96 & 80 & 4 & 100 & 20 & 120 & 16 & 4 \\
\hline Buyer & 120 & - & - & - & - & - & - & $20^{\star *}$ \\
\hline
\end{tabular}

* Excluding farmer costs.

* * The tax amount is paid by the buyer in the price of the goods.

Source: Developed by the author

As we can see, the taxpayer (legal entity) has value added measured by the difference between the total sale amount and the total purchase amount from all business entities that are VAT payers.

The object of taxation value added is created by all independent participants of the production and commercial process. If you imagine the company as a whole with a complete production and trade cycle (from own raw materials and manufacturing of production equipment to sale of finished products), the total value of the sold products would be the result of the company 's own activity, and the value added tax base was considered net sales amount.

Simplicity, economic and organizational-technical characteristics provided value-added tax advantages over other types of turnover taxation or universal excise taxes.

Thus, with the help of VAT, it is possible to regulate the wage fund and price. It provides an opportunity to eliminate unnecessary links of economic management. In addition, the tax makes it possible to determine the real value of each product relatively accurately and, on the basis of this, to form the basis of economic proportions.

VAT has an internal «built-in» mechanism for mutual reconciliation of tax liabilities by payers. He does not know the discrimination of payers depending on their role and place in the economic process, VAT is neutral in relation to the movement of goods and services, placement of resources.

VAT through increased influence on the price level can be used in anti-inflationary processes, as VAT makes it possible to automatically obtain market profits generated by inflation and thus contain unjustified price increases.

Among the most valuable economic advantages of the value added tax is its ability not to distort the behavior of payers as participants in the business process, not to change economic decisions under the influence of VAT.

However, it must also be borne in mind that the use of value-added tax is not only positive. A number of controversial, or negative, points make the discussions about the need to levy this tax very relevant.

Being, in principle, a tax on final consumption, which falls on the population and the budget sphere, VAT at a sufficiently high rate and high inflation rates becomes one of the factors that constrain the development of production. 
This is due to the increase in prices and the containment on the basis of this possibility of payment by the buyer of goods (works, services). Of course, these funds will return to the buyer (either from the budget or at the moment when he sells the products himself), but provided that the chain of acts of sale continues or comes with a certain step of «delay», when partially these funds will be devalued by inflation.

In addition, the application of VAT rates at the level of 20-28\% stimulates both inflation processes in general and negatively affects high-tech and knowledge-intensive production. Therefore, although the applied rate makes value-added tax one of the main sources of budget filling, the appearance of its deficit is very misleading. It is in this regard that economists most often associate the optimal VAT rate with the level of $15-18 \%$.

Having taken a dominant position in the world tax system, VAT retains some features related to the possibility of avoiding its payment. Therefore, in the VAT system, perfect and comprehensive accounting, registration of all transactions are of exceptional importance.

World experience also shows that the important problem of introducing a value-added tax is the preparation of public opinion, explanatory work with payers and the training of tax officials.

The economic qualities of VAT have been properly assessed by the business world. It is no accident that there have been proposals to replace corporate income tax with value-added tax. Compared to corporate income tax, VAT has the fiscal and ethical advantages that make individual intra-firm, so-called transfer prices unfavourable, and it does not respond to business tricks such as fictitious property write-off, accelerated depreciation, the practice of raising costs, manipulating interest on debt.

That is why the value-added tax has gained a reputation as a unique fiscal instrument for optimal resource allocation. The socially necessary redistributive micro and macroeconomic effects of this tax proved to be most socially acceptable. This is why VAT attracts the attention of countries that are trying to boost economic growth.

As a result of the study of foreign experience in the taxation of value added within the framework of Ukraine 's integration into the European Union and the possibility of adapting it to domestic practice, the following measures were proposed to reform the tax system of Ukraine: the introduction of differentiation of value added tax rates, which will allow for a relatively fair distribution of the tax burden among its actual payers; introduce an automated information exchange system such as the European Union VIES; eliminate most of the unjustified benefits that are not of social importance; outreach and partnerships with payers; liberalization of reporting, acceptance and audit processes; use of progressive methods to select payers for verification.

At the same time, VAT itself is not always able to bring success. Through its administrative gravity, the valueadded tax is not effective in those countries that have not yet reached the level of an orderly market economy, high fiscal discipline, civilized social behavior.

\section{Список використаних джерел}

1. Бюджетно-податкова політика. URL: http://posibniki.com.ua/catalog-budzhetno-podatkova-politika

2. Дахнова О. Є., Білик М. Ю. Оцінка індикаторів фріскальної ефрективності ПДВ в Україні. Молодий вчений, № 7, 2017. 593 c.

3. Доходи бюджету України. URL: http://cost.ua/budget/revenue/

4. Офіційний веб-сайт Державної служби статистики. URL: https://ukrstat.gov.ua/

5. Офріційний веб-сайт міністерства фрінансів. URL: https://minfin.com.ua/

6. Податковий кодекс України. URL: http://zakon3.rada.gov.ua

7. Калінеску Т. В., Пономарьова І. В., Альошкін С. В. Соціальні аспекти податкової політики: підручник. Сєвєродонецьк: вид-во СНУ ім. В. Даля, 2015. 384 с.

8. Оксенюк О. І. Фіскальна ефрективність податку на додану вартість в економіці України : авторефр. дис. на здобуття наук. ступення канд. екон. наук : спец. 08.00 .08 ; Львівський нац. університет ім. Івана Франка. Львів, 2016. 20 с.

9. James K. Exploring the origins and global rise of VAT. Tax Analyst. 2011. № 2. C. 15-16

10. William F. Fox (March 13, 2002). «History and Economic Impact: Sales Tax History». University of Tennessee Knoxville, Center for Business and Economic Research. URL: http://cber.bus.utk.edu/staff/mnmecon338/foxipt.pdf.

\section{References}

1. Fiscal policy. URL: http://posibniki.com.ua/catalog-budzhetno-podatkova-politika

2. Dakhnova O. E., Bilyk M. Yu. (2017). Assessment of indicators of fiscal efficiency of VAT in Ukraine. Young Scientist, 7, $593 \mathrm{p}$.

3. Budget revenues of Ukraine. URL: http://cost.ua/budget/revenue/

4. Official website of the State Statistics Service. URL: https://ukrstat.gov.ua/

5. Official website of the Ministry of Finance. URL: https://minfin.com.ua/

6. Tax Code of Ukraine. URL: http://zakon3.rada.gov.ua

7. Kalinescu T. V., Ponomareva I. V., Aleshkin S. V. (2015). Social aspects of tax policy: textbook. Severodonetsk: publishing house VNU named after V. Dalia, $384 \mathrm{p}$.

8. Oksenyuk O. I. (2016). Fiscal efficiency of value added tax in the Ukrainian economy: autoref. diss. for the application scientific. feet cand. econ. sciences: special. 08.00.08; Lviv nats. Ivan Franco University. Lviv, 20 p.

9. James K. (2011). Exploring the origins and global rise of VAT. Tax Analyst, 2. 15-16.

10. William F. Fox (March 13, 2002). History and Economic Impact: Sales Tax History. University of Tennessee Knoxville, Center for Business and Economic Research. URL: http://cber.bus.utk.edu/staff/mnmecon338/foxipt.pdf. 


\section{ДАНІ ПРО АВТОРА}

Слюсар Світлана Тимофіївна, кандидат економічних наук, доцент кафедри фрінансів, обліку і оподаткування Університет Григорія Сковороди в Переяславі

вул. Сухомлинського 30, м. Переяслав, 08401, Україна

e-mail: devko89@ukr.net

ORCID ID: 0000-0002-3068-6387

Researcher ID: T-1176-2019

\section{ДАННЫЕ ОБ АВТОРЕ}

Слюсар Светлана Тимофеевна, кандидат экономических наук, доцент кафедры фринансов, учета и налогообложения

Университет Григория Сковороды в Переяславе

ул. Сухомлинского 30, г. Переяслав, 08401, Украина

e-mail: devko89@ukr.net

\section{DATA ABOUT AUTHOR}

Sliusar Svitlana, $\mathrm{PhD}$ (Economics), associate professor of finance, account and taxation

Hryhorii Skovoroda University in Pereiaslav

Sukhomlynsky Str. 30, Pereyaslav, 08401, Ukraine

e-mail: devko89@ukr.net 